\title{
Nurses and Patients' Perceptions about Patient's Rights Before and After Implementation of Training Sessions for Nurses
}

\author{
Nama Mohammed Abd Allah Abdu, Prof. Seham Ibrahim Hamouda,Dr. Sanaa \\ Abd El Azeem Ibrahim, Dr. Mona Abdul El Sabour Hassan \\ B. Sc of Nursing Zagazig university, Professor of Nursing Administration- Faculty \\ of Nursing- Tanta-University Assistant Professor of Nursing Administration- Faculty \\ of Nursing-Port-Said University, Assistant Professor of Family and Community \\ Health Nursing- Faculty of Nursing Port- Said University
}

\begin{abstract}
Back ground: Patient rights have recently become the center of national attention in health care practice. aim : The aim of the study was to assess nurses and patients perceptions about patient's rights before and after implementation of training sessions for nurses in Port Said Hospitals Subject and Methods : Pre \&post test design was used in this study in two different health care sectors (general \& private). The subjects of this study consisted of two groups: Nurses group:-All nurses at selected hospitals inpatient units was included in the study with a total numbers (97).Patients group include 135 from two selected hospitals. Data were collected using questionnaire sheet containing three parts. First parts personal characteristics of nurses, second part structured questionnaire sheet for nurses about personal and job characteristics, finally questionnaire sheet for nurses and patients to assess patient's rights. Results: The main results of the study revealed that highly improvement $(\uparrow 37$. 5 ) in nurse's knowledge and perceptions about patient's rights after implementation of the educational sessions. More over, highly improvement in patient's perceptions regarding their rights. Also was detected follow implementation of sessions for nurses were statistically significant association between patient perceptions and their age. Recommendation: Based on the findings. It was recommended the following. On -job training and continuous education to enhance nurse's knowledge about patient's rights. Provision of posters \& booklets about bill of patient rights within the hospitals available to see by nurses and patients.
\end{abstract}

Key Words: Nursing ethics, code of ethics, bill of patients rights 


\section{INTRODUCTION}

One of most fundamental thing that nurse can do to get support for ethical practice is to explicitly identify relationships with patients, families, and communities as the foundation of ethical nursing. Its important to be clear that ethics is more than making good decisions and to name care issues appropriately as ethical ones (Cowen $\boldsymbol{\&}$ Moorhead , 2011). For this the American Nursing Association (ANA) code of ethics was established in 1950 for nurses' guides the practicing nurse how to use her professional skills to provide the most effective holistic care possible, such as serving as patient advocate and striving to protect the health, safety, and rights of each patient (Craven\& Hirnle, 2007).

The (ANA) spells out of obligations to clients and society, some of those obligations include maintaining client's privacy and safety, improving the standard of nursing care, and assuming responsibility for ones nursing action. This ethical code, which provide broad principles for determining and evaluating nursing care (Craven\& Hirnle , 2007). In 1973 the American Hospital Association (AHA) established a patient's bill of rights which includes the rights and responsibility of clients receiving care in hospital. (Ellis, 2008). And also AHA encourages health care institution to tailor the bill of rights to their patient by translating and / or simplifying the language of their bill of rights, as may be necessary to ensure that patient and their family understands their rights and responsibility (Craven \& Hirnle, 2003).

Patients rights are the services created to improve patients' health and protection of their rights in the welfare and health fields. It offers some guidance and protection to patients by stating the responsibilities that hospital and its staff have towards patients and their families during hospitalization (Ellis, 2001). Neglecting patients' rights in a health care system can give rise to a challenging situation between health care providers and patients. (Almoajel 2012). Therefore this study was conducted for the purpose of measuring perceptions of patients and nurses regarding patients' rights and implementing training session for nurses in order to help them to achieve appropriate level of awareness regarding patients' rights and provide care with ethical manner.

\section{SUBJECT AND METHODS}

Aim of the present study was to:- assess nurses and patients perceptions about patient's rights before and after implementation of training sessions for nurses in Port Said Hospitals 


\section{Research Objectives is to:}

1. Assess patient's perceptions about their rights in the selected hospitals.

2. Assess nurse's awareness about patients' rights in the selected hospitals.

3. Apply training sessions for nurses about patients' rights in the selected hospitals.

4. Compare between awareness of nurses before and after implementation of training sessions for nurses regarding patient rights in the selected hospitals.

5. Compare between perception of patients before and after implementation of training sessions for nurses regarding patient rights in the selected hospitals

\section{Research design:}

Quasi-experimental with Pre and post test design was used in this study

\section{Settings of the study:}

The study was conducted in two different hospitals in Port Said City, representing two different health care sectors, governmental sector (Port said general hospital) and Private sector namely Al-Soliman hospital.

\section{Study population. The subjects of this study consisted of two groups:}

\section{1-Nurses group:-}

All nurses of the selected hospitals of the selected inpatient units were detected in the study

\section{2-Patients group:-}

Sample sizes of patients were calculated using the following equation.

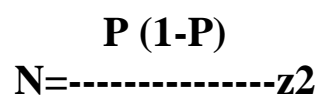

\section{D2}

(Brown and Hollander, 1977)

Finally the total sample of patients was 135 patients in two selected hospitals

\section{Tool for data collection:}

The study data was collected be using one tool containing three parts.

*First part: Consists of items related to personal characteristics of nurse's e.g. name, educational level, job position, age, sex, experience, social status, etc. and demographic characteristics for patients such as: name, age, sex, education, job, social status, and their admission department.

* Second Part: a structured questionnaire sheet for nurses developed by researcher about Knowledge of nurses regarding patients' rights it includes questions such as: 
definition of patients' rights, Training courses, posters or booklets on the rights of the patient, and patients recognizing their rights by other health provider and open questions includes list of patients' rights, patients complain, and number of courses.

*Third part: a questionnaire sheet for nurses and patients regarding their perception of patients' rights, it was concerned with the patients bill of rights developed by (Carol etal., 2001) and contains 89 items divided to 16 sub item

\section{*Field work:}

Data were collected by the investigator over 6 months period from first of April to end of September 2012. The study was conducted through four phases: Pre-planning, planning, implementation and evaluation.

* Phase I (pre planning): before starting-up session's nurses were assessed using proportioned tool nurses' and patients perception related to patient's rights

* Phase II (sessions planning): the sessions were designed using the baseline information gathered in phase I. It was developed based on the identified nurse's needs and patients

*Phase III (session's implementation): the training two sessions were implemented for each group of nurses in each hospital. It lasted for two months, in weekly sessions, each session take about two hours per day for each group, each group about 5-10 nurses, the time of session at morning shift or in the evening shift of a day, the sessions were presented in clear and concise form, and focused on the point of learning, using different teaching methods such as lecture, and discussions the contain of session was include definition of patients rights and bill of rights.

*Phase IV (evaluation): After session's implementation, a post - test was done immediately. the study tool were used after one month of implementation to evaluate the effect of training sessions on the nurse's perception related to patients' rights by comparing the results before sessions with those after sessions..

After obtaining the official permission to conduct the study and after finalization of tool, the investigator met with the nurses individually and explained to them the purpose of the study, the consent of each eligible nurses were obtained before their participation, those nurses were given the self administered written questionnaire sheet and asked to fill it out.. Time needed for filling self- administered questioner ranged between 25 to 30 minutes.

\section{Ethical Considerations:}

A brief explanation of the aim of the study was given to director, head nurse, and each nurse's and patients participant in the study. Stressing on confidentiality of the collected information, to be familiar with the importance of their participation and to take their agreement for included in the study. The researcher emphasized that participation were absolutely voluntary and each nurse have the right to withdraw from the study at any time with no questions asked as well as confidentiality was assured. 


\section{RESULTS}

Table (1): Illustrated an improvement in nurse's knowledge in both studied hospitals after implementation of the sessions where an increase in nurses knowledge working at Port Said general hospital from $(58.2 \%)$ before sessions to ( $90.9 \%$ ) after implementation of the sessions with percentage change of ( $\uparrow 56.3 \%)$, Also an improvement in nurse's knowledge detected in Al Soliman private hospital where it increase $(61.9 \%)$ before sessions to $(83.3 \%)$ ) after implementation of the sessions with percentage change of $(\uparrow 34.6 \%)$

Table (2): Revealed an improvement of the nurse's perception regarding patients rights after implementation of the educational sessions, the highest mean of change was in area of patient rights to obtain confidentiality of patients records where $(4.69 \pm 0.44 \%)$, while the lowest one was in area of patients rights to refuse prescribed treatment $(3.68 \pm$ $1.24 \%)$.

Table (3): Illustrated an improvement in all areas of the patients perceptions in all area in patents rights after implementation of the sessions for nurses, except in area of patients rights to accept or refuse participation in research $(14.06 \pm 49.09 \%)$ and patients rights to defend their rights in the hospital, the highest mean of change was in areas of patients rights to get high level of security in the hospital $(4.63 \pm 0.59 \%)$. 
Table (1): Nurses knowledge and sources of their knowledge regarding patient's rights before and after implementation sessions

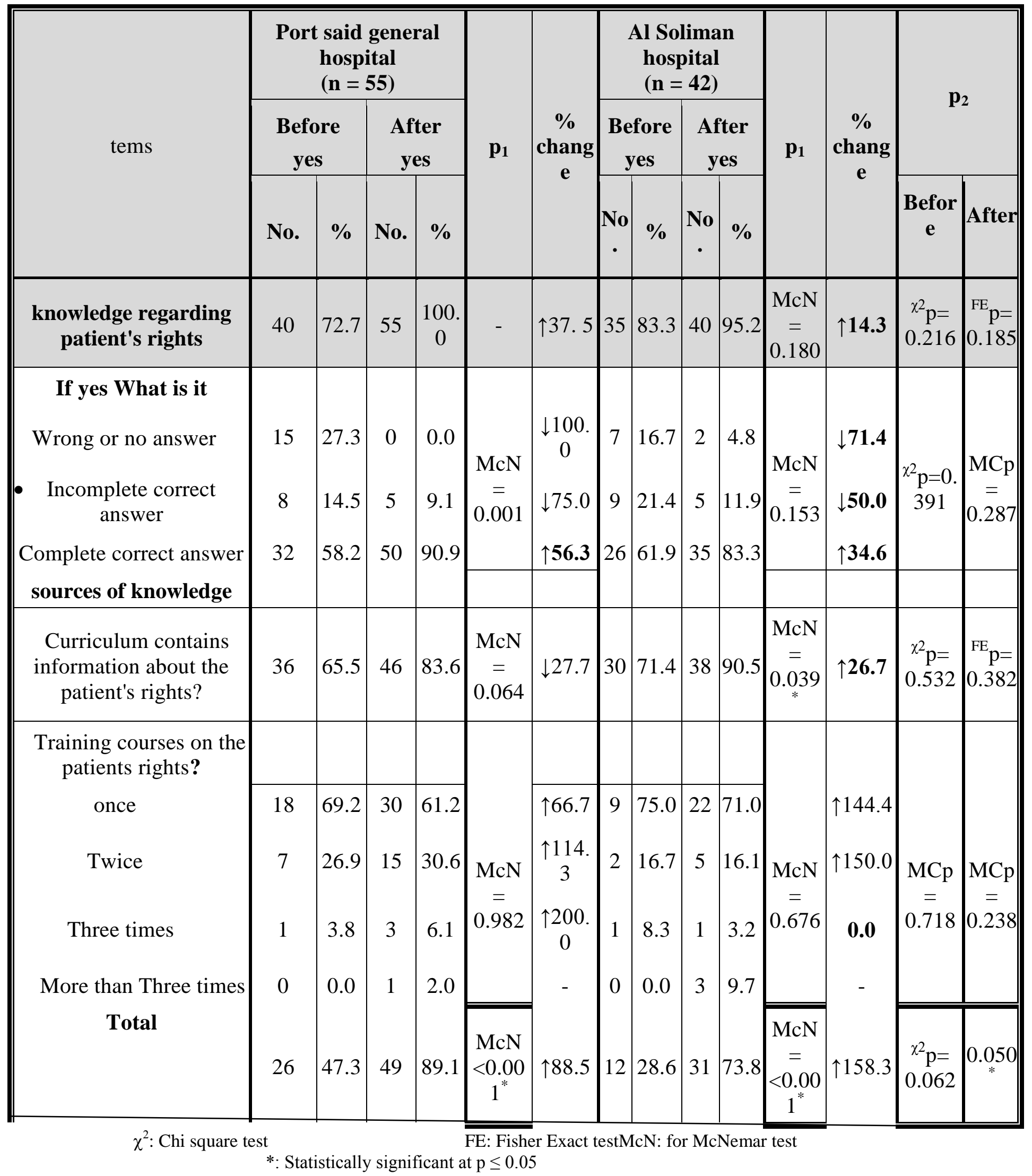


Table (2): Total mean change of nurse's perception about patient's rights before and after training sessions

\begin{tabular}{|c|c|c|c|c|}
\hline \multirow{2}{*}{ items } & \multicolumn{2}{|c|}{$\begin{array}{c}\text { Total } \\
\text { Mean } \pm \text { SD }\end{array}$} & \multirow[b]{2}{*}{$\mathbf{p}$} & \multirow{2}{*}{ Total change } \\
\hline & before & after & & \\
\hline 1-Patients rights to considerate a respectful care & $4.41 \pm 0.55$ & $4.65 \pm 0.40$ & $0.001^{*}$ & $7.42 \pm 18.51$ \\
\hline $\begin{array}{l}\text { 2-Patient rights to get information concerning } \\
\text { diagnoses, treatment and prognosis }\end{array}$ & $4.21 \pm 0.56$ & $4.59 \pm 0.44$ & $<0.001^{*}$ & $11.07 \pm 20.72$ \\
\hline 3-Patient rights to privacy & $4.12 \pm 0.64$ & $4.57 \pm 0.42$ & $<0.001^{*}$ & $14.44 \pm 24.77$ \\
\hline $\begin{array}{c}4 \text {-Patient rights to obtain confidentiality of } \\
\text { patients records }\end{array}$ & $4.19 \pm 0.66$ & $4.69 \pm 0.44$ & $<0.001^{*}$ & $15.15 \pm 25.28$ \\
\hline $\begin{array}{c}\begin{array}{c}\text { 5-Patients rights to make decisions about plan of } \\
\text { care }\end{array} \\
\end{array}$ & $3.69 \pm 0.77$ & $4.32 \pm 0.58$ & $<0.001^{*}$ & $22.84 \pm 33.94$ \\
\hline $\begin{array}{l}\text { 6-Patients rights to ask for health services in the } \\
\text { hospital }\end{array}$ & $4.23 \pm 0.62$ & $4.63 \pm 0.41$ & $<0.001^{*}$ & $12.15 \pm 21.07$ \\
\hline $\begin{array}{c}\text { 7-Patients rights to get high level of security in the } \\
\text { hospital }\end{array}$ & $4.26 \pm 0.70$ & $4.66 \pm 0.40$ & $<0.001^{*}$ & $13.28 \pm 28.39$ \\
\hline $\begin{array}{l}\text { 8-Patients rights to accept or refuse } \\
\text { participation in research }\end{array}$ & $3.81 \pm 0.81$ & $4.43 \pm 0.61$ & $<0.001^{*}$ & $21.57 \pm 32.25$ \\
\hline $\begin{array}{l}\text { 9-Patients rights to have hospital response for } \\
\text { patients need or demand }\end{array}$ & $4.19 \pm 0.69$ & $4.65 \pm 0.42$ & $<0.001^{*}$ & $14.94 \pm 29.56$ \\
\hline 10-Patients rights to refuse prescribed treatment & $3.39 \pm 1.05$ & $3.68 \pm 1.24$ & 0.067 & $20.59 \pm 59.15$ \\
\hline 11-Patient rights to complains & $4.28 \pm 0.64$ & $4.55 \pm 0.51$ & $0.002^{*}$ & $9.20 \pm 24.59$ \\
\hline $\begin{array}{l}\text { 12-Patient rights to accept or refuse visiting and } \\
\text { use recreation facilities }\end{array}$ & $3.98 \pm 0.77$ & $4.57 \pm 1.43$ & $0.001^{*}$ & $21.83 \pm 51.28$ \\
\hline $\begin{array}{c}\text { 13-Patient rights to sign consent for treatment } \\
\text { /before surgery }\end{array}$ & $4.23 \pm 0.71$ & $4.44 \pm 0.71$ & $0.021^{*}$ & $8.36+28.46$ \\
\hline \begin{tabular}{|c|}
$\begin{array}{c}\text { 14-Patients rights to defend patients rights in the } \\
\text { hospital }\end{array}$ \\
\end{tabular} & $4.20 \pm 0.73$ & $4.62 \pm 0.48$ & $<0.001^{*}$ & $14.57 \pm 30.87$ \\
\hline $\begin{array}{l}\text { 15-Patents rights to know hospital rule and } \\
\text { regulations related to patients care }\end{array}$ & $4.13 \pm 0.72$ & $4.41 \pm 0.61$ & $0.007^{*}$ & $11.60 \pm 33.13$ \\
\hline $\begin{array}{l}\text { 16-Patients rights to get continuing health care } \\
\text { after discharge }\end{array}$ & $4.23 \pm 0.75$ & $4.52 \pm 0.61$ & $0.003^{*}$ & $12.11 \pm 35.25$ \\
\hline Total & $4.12 \pm 0.48$ & $4.53 \pm 0.37$ & $<0.001^{*}$ & $11.45 \pm 17.49$ \\
\hline
\end{tabular}

Paired t-test for comparing between before and after

*: Statistically significant at $\mathrm{p} \leq 0.05$ 
Table (3): Total mean change of patients perception regarding their rights before and after training sessions

\begin{tabular}{|c|c|c|c|c|}
\hline \multirow{2}{*}{ items } & \multicolumn{2}{|c|}{ Total Mean \pm SD } & \multirow{2}{*}{$\mathbf{p}$} & \multirow{2}{*}{ Total change } \\
\hline & before & after & & \\
\hline 1-Patients rights to considerate a respectful care & $4.13 \pm 0.83$ & $4.57 \pm 0.53$ & $<0.001^{*}$ & $17.91 \pm 41.76$ \\
\hline $\begin{array}{l}\text { 2-Patient rights to get information concerning } \\
\text { diagnoses, treatment and prognosis }\end{array}$ & $4.24 \pm 0.54$ & $4.48 \pm 0.59$ & $0.001^{*}$ & $7.86 \pm 25.41$ \\
\hline $\begin{array}{l}\text { 3-Patient rights to have every consideration of } \\
\text { privacy }\end{array}$ & $3.87 \pm 0.75$ & $4.25 \pm 0.61$ & $<0.001^{*}$ & $14.97 \pm 34.82$ \\
\hline $\begin{array}{l}\text { 4-Patient rights to obtain confidentiality of } \\
\text { patients records }\end{array}$ & $4.10 \pm 0.84$ & $4.41 \pm 0.62$ & $<0.001^{*}$ & $13.52 \pm 37.25$ \\
\hline $\begin{array}{l}\text { 5-Patients rights to make decisions about plan of } \\
\text { care }\end{array}$ & $3.51 \pm 0.81$ & $3.86 \pm 0.85$ & $0.002^{*}$ & $17.60 \pm 42.77$ \\
\hline $\begin{array}{c}\text { 6-Patients rights to ask for health services in the } \\
\text { hospital }\end{array}$ & $4.10 \pm 0.64$ & $4.57 \pm 0.51$ & $<0.001^{*}$ & $14.89 \pm 25.32$ \\
\hline $\begin{array}{l}\text { 7-Patients rights to get high level of security in the } \\
\text { hospital }\end{array}$ & $4.08 \pm 0.94$ & $4.63 \pm 0.59$ & $<0.001^{*}$ & $21.53 \pm 39.22$ \\
\hline $\begin{array}{c}\text { 8-Patients rights to accept or refuse participation in } \\
\text { research }\end{array}$ & $3.83 \pm 0.81$ & $4.05 \pm 0.81$ & $0.045^{*}$ & $14.06 \pm 49.09$ \\
\hline $\begin{array}{l}\text { 9-Patients rights to have hospital response for } \\
\text { patients need or demand }\end{array}$ & $4.03 \pm 0.90$ & $4.16 \pm 0.69$ & 0.194 & $10.78 \pm 40.67$ \\
\hline $\begin{array}{c}\text { 10-Patients rights to accept or refuse prescribed } \\
\text { treatment }\end{array}$ & $3.0 \pm 1.30$ & $3.38 \pm 1.25$ & $0.024^{*}$ & $38.42 \pm 79.30$ \\
\hline 11-Patient rights to present patients complains & $4.11 \pm 0.87$ & $4.45 \pm 0.71$ & $0.001^{*}$ & $15.79 \pm 40.05$ \\
\hline $\begin{array}{l}\text { 12-Patient rights to accept or refuse visiting and use } \\
\text { recreation facilities }\end{array}$ & $3.70 \pm 0.89$ & $3.93 \pm 0.85$ & $0.031^{*}$ & $13.93 \pm 42.22$ \\
\hline $\begin{array}{c}\text { 13-Patient rights to sign consent for treatment } \\
\text { /before surgery }\end{array}$ & $4.04 \pm 0.83$ & $4.35 \pm 0.70$ & $0.001^{*}$ & $15.27 \pm 47.98$ \\
\hline $\begin{array}{l}\text { 14-Patients rights to defend patients rights in the } \\
\text { hospital }\end{array}$ & $3.99 \pm 0.90$ & $4.44 \pm 0.66$ & $<0.001^{*}$ & $21.13 \pm 52.02$ \\
\hline $\begin{array}{l}\text { 15-Patents rights to know hospital rule and } \\
\text { regulations related to patients care }\end{array}$ & $3.91 \pm 0.89$ & $4.13 \pm 0.78$ & $0.040^{*}$ & $13.03 \pm 40.70$ \\
\hline $\begin{array}{l}\text { 16-Patients rights to get continuing health care } \\
\text { after discharge }\end{array}$ & $4.11 \pm 0.82$ & $4.37 \pm 0.70$ & $0.009^{*}$ & $13.62 \pm 46.52$ \\
\hline Total & $3.96 \pm 0.64$ & $4.30 \pm 0.47$ & $<0.001^{*}$ & $12.70 \pm 29.14$ \\
\hline
\end{tabular}




\section{IDISCUSSION}

The result of present study recorded an improvement in nurses knowledge about patients rights after implementation of sessions, this result is in the same line with Reid, etal. (2008) clarified that nurses awareness of patients rights is essential to provide patient with legal rights in issues concerning their care and made health care workers legally responsible for treatment of their patients. While the result was contrary with Hassan (2012) who found that most of studied subjects had unsatisfactory knowledge about patient's rights and the rest had satisfactory

From researcher point of view achievement of patients rights lead to decrease the conflict between the patients and nurses and make the work environment more comfortable.

Based on the result of present study an improvement in nurses perceptions in most areas of patients rights were detected after implementation of educational sessions the highest improvement in nurses perception was related to patient rights to make decisions about plan of care. This finding is consistent with Zülkar, and Ulusoy, (2001) who reported that all patients have fundamental right to make decision about plan of care, refusing any provider sharing in solving his/ her problem and refusing the treating physician after discharge. Additionally, the patients should have the right to be given a reasonable time to make decision about their care. On the other hand Amir, etal (2009) added that healthcare professionals should introduce measures to encourage patients to contribute to the clinical decision making process more proactively.

Results of the current study revealed an improvement in the most areas of patient's perceptions about their rights after implementation of the educational sessions for nurses, the improvement was detected in rights of patient to accept or refuse prescribed treatment including examinations, tests and diagnostic procedures. This result is in consistent with Albishi, (2004). who stressed that the patient right to refuse medical care or treatment to extent permitted by law, and in collaboration with his / her physician, to make involving his / her health care including the acceptance or refused of treatment and the use of advanced directive

Based on the result of present study an improvement in nurses perceptions in most areas of patients rights were detected after implementation of educational sessions the highest improvement in nurses perception was related to patient rights to make decisions about plan of care. This finding is consistent with Zülkar, and Ulusoy, (2001) who reported that all patients have fundamental right to make decision about plan of care, refusing any provider sharing in solving his/ her problem and refusing the treating physician after discharge. Additionally, the patients should have the right to be given a reasonable time to make decision about their care. On the other hand Luther, etal,. (1997) found that $79 \%$ of their patients preferred to leave decision making to their doctors. As far as decision making is concerned, almost half of the patients waived their right to decide in favor of their attending physician, 
The result of the present study shows that patients' perception about their rights in Al Soliman private hospital was better than perception of patients in Port Said general hospital, this is may be due to that the patient in Al Soliman hospital perceive their rights more respect from nurses because they are paid for their service, and they complain for any deficiency of their rights. This result with the same line with Pars poor, et al (2012) that clarifies patients acquire their needed information through asking questions actively and believe that the medical team is accountable; this is not approved by healthcare providers especially in teaching hospitals.

On the same line Makhashvili,\& VanVoren , (2013) stated that the amount of unsatisfied patients was much higher in the teaching hospital than the other, so it requires special considerations, and the private hospital allows the patients to choose the doctor who treats them at a time and in circumstances that suits them. This is provided their doctor has an arrangement with that hospital and able to provide the services they will need. And also Joolaee, etal. (2008) clarifies that the nurses should treat the patients as human being and have the care regardless their age, sex, religion, and source of payment for services

\section{CONCLUSION}

From the findings of the current study, it was concluded that there was an improvement in nurse and patients perception regarding patients rights in both studied hospitals (Port said general hospital \& Al Soliman ) after implementation of educational sessions, an improvement in nursing knowledge was also detected

\section{RECOMMENDATIONS}

Based on the study findings, the following recommendations are suggested: On -job training and continuous education in order to enhance nurses knowledge\& perception about patients rights-Activate complain box at hospitals to discover the patients complain from inhuman services or neglecting patients rights. Measure patient's satisfaction related receiving rights during period of hospitalization. Provision of posters \& booklets about bill of patient rights within the hospitals available to see by nurses and patients

\section{REFERENCES}

Albishi, A. (2004): The Saudi Patients', Physicians, and Nurses' Perceptions of and Lived Experiences with Patients' Rights in Saudi Arabia: A Qualitative Phenomenological Study. Doctoral Dissertation. Faculty of ,GeorgeMansonUniversity.

Almoajel M, A. (2012).: Hospitalized Patients Awareness of Their Rights in Saudi Governmental Hospital. Middle-East Journal of Scientific Research 11 (3): 329-335, 2012

Amir M, Rabbani, M, Z, \& Parvez, M, B. (2009): Informed consent in elective surgical procedures: "What do the patients think?" J Pak http://journals.tums.ac.ir/Med Assoc; 59(10).p. p 679-82. 
Carol, t., Lillis, c. and Lemone, P. (2001): Fundamentals of nursing the art and science of nursing care. 4thed. New York: Lippincott Company, p. 87-89

Cowen, S. \&Moorhead , S . (2011) : Current issues in nursing. $8^{\text {th }}$ ed. USA. mospy Elsevier Company, P.620

Craven, R.F., \& Hirnle, C.J., (2007): Fundamentals of nursing Human health and function. 5th ed, Philadelphia: Walters's kuwer business, p .91

Craven, R.F., \& Hirnle, C.J., (2003): Fundamentals of nursing 4thed New York: Lippincott Williams\& Wilkins Company, P.p 88, 91

Ellis, J.R., (2008): Nursing today's in world. 9thed. London: Lippincott Williams\& Wilkins, p. 348

Ellis, J.R., (2001): Nursing in today's world, challenges, Issues and trends. 7thed. New York: Lippincott Company, p. 358

EL-Sayed, M. N (2003): Patients Rights as Perceived by Health Care Providers and Patients, Unpublished Master Thesis, Nursing Administration Department, Faculty of Nursing Zagazig University, E GYPT.

Hassan, M.(2012): Assessment of professional ethics practiced by nurses working in primary health care centers Unpublished Master Thesis, community and family health nursing , Faculty of Nursing- Suez Canal University, E GYPT

JoolaeeS.,TschudinV.,Nikbakht-NasrabadiA.\&ParsaYekta

,Z.(2008):Factors

affecting patients 'rights practice the lived experiences of Iranian nurses and physicians . International Nursing Review 5(5),55-61

Luther, K, Pais , M, Silberblatt, G (1997): Promoting positive outcomes from patient complaints, Orthopedics Nurses 1997; 16(5): 39n42 .

Makhashvili N,\&VanVoren R (2013):Balancing Community and Hospital Care: A Case Study of Reforming Mental Health Services in Georgia. PLoS Med 10(1): e1001366. doi:10.1371/journal.pmed.1001366

Parsapoor A, Mohammad K,and MalekAfzali H, (2012): Necessity of observing patient's rights: a survey on the attitudes of patients, nurses and physicians. J Med Ethics Hist Med; (5) .2.

Reid, B, \&Kane , K \& Curran ,C. (2008): district nursing workforce planning: a review of the methods, British Journal of Community Nursing, 13(11),.525-530.

Zülkar, F.\&Ulusoy, M.F.(2001): Are patients aware of their rights ?ATurkish study. Nursing Ethics,8 (6),487-498 


\section{ادراك الممرضاتَّ و المرضى لحقوق المرضى قَبَلَ وَبَعد تطبيق الجلسات التدريبيةِ للممرضاتِ المرضي}

نعمة محمد عبداللة عبده، ا. د/ سهام إبراهيم حمودة، ا.م. د / سناء عبد العظيم إبراهيم،

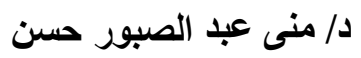

بكالوريوس تصريض جامعة الزقازيق، أستاذ إدارة التصريض،كلية التصريض جامعة طنطا ، أستاذ مساعد إدارة

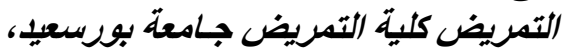

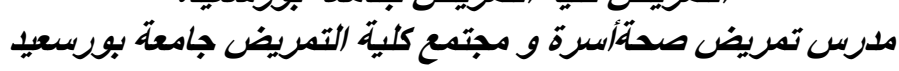

\section{الخلاصة}

أصبحتْ حقوق المرضى مركزَ الانتباه العالمي فى الممارسات الطبية مؤخر اً. لذللك كان الهدف من هذه الدراسة

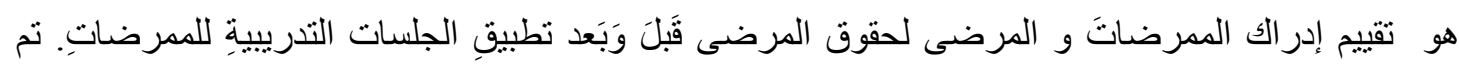

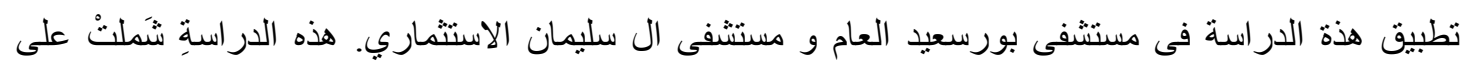

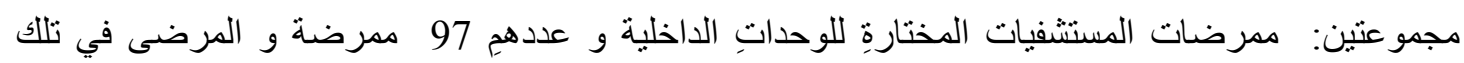

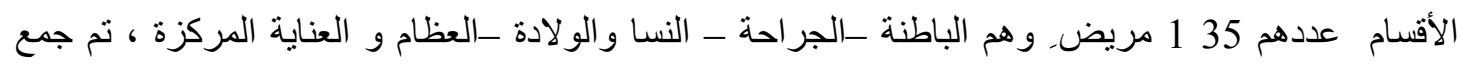
البيانات باستخدام أداةِ واحدة تَحتوي على ثلاثة أجزاءِ الجزء الأول يتكون من البنود ذات الصلة بالخصائص

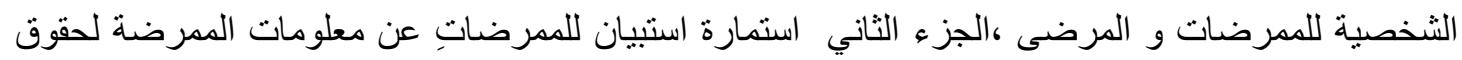
المرضى الجزء الثالث ،استمارة استبيان للممرضات و المرضى عن حقوق المريض وقد أظهرت النتائج و وجود تحسينَ ملحوظ في معرفِة الممرضاتِ لحقوقِ المرضى بعد تطبيقِ الجلساتِ التدريبية للممرضات(

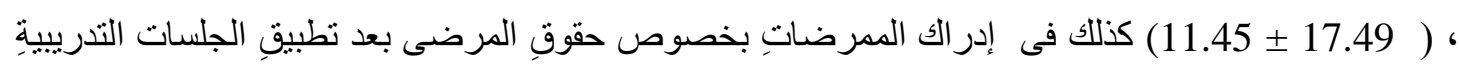

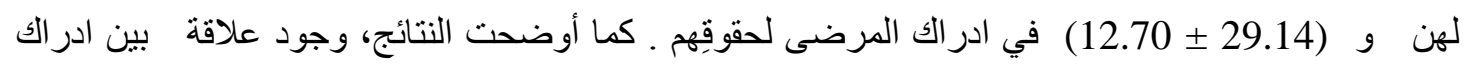

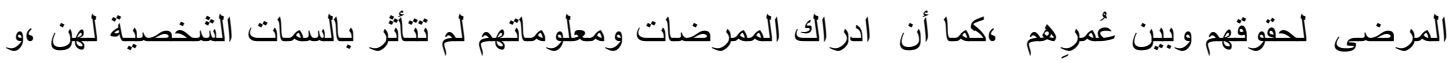

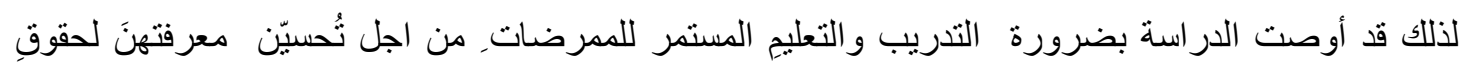

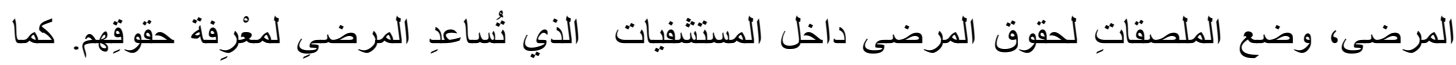
أوصت النتائج بضرورة تصميم استمارة لتقييم كيفية أداء الممرضات لحقوق المرضى عند تقديم الخدمات الصحية للمرضى و التعامل معهم التي بدور ها تعكس نقاط الضعف وبالتالي تحسينها و لابد من وجود نظام

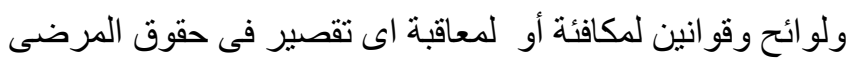

